African Crop Science Journal by African Crop Science Society is licensed under a Creative Commons Attribution 3.0 Uganda License. Based on a work at www.ajol.info/ and www.bioline.org.br/cs DOI: http://dx.doi.org/10.4314/acsj.v24i1.2S

\title{
MAGNITUDE OF GENOTYPE X ENVIRONMENT INTERACTION FOR BACTERIAL LEAF BLIGHT RESISTANCE IN RICE GROWING AREAS OF UGANDA
}

\author{
R.K. LUSSEWA, R. EDEMA ${ }^{1}$ and J. LAMO ${ }^{2}$ \\ ARI-Ukiriguru, Mwanza, Tanzania \\ ${ }^{1}$ Department of Agricultural Production, Makerere University, P. O. Box 7062, Kampala, Uganda \\ ${ }^{2}$ Namulonge National Crop Resource Research Institute, Kampala, Uganda.
}

Corresponding author: rkilloh@yahoo.com

\begin{abstract}
Bacterial leaf blight (BLB) of rice (Oryzae sativa L.), caused by Xanthomonas oryzae pv. oryzae, is a major constraint in most lowland rice producing areas of Uganda. The disease is widely distributed in all irrigated and rainfed lowland rice ecosytems in the country. The pathogen (Xoo) is highly variable and its control is rather difficult. Development and deployment of host resistance is the only effective means of BLB management. The objective of this study was to determine the magnitude of genotype by environment $(\mathrm{G} \times \mathrm{E})$ interaction for resistance to bacterial leaf blight in rice in Uganda. A study comprised of two sets of germplasms, a total of 30 rice genotypes comprising of 13 lines with varying levels of BLB resistance, and $17 \mathrm{~F}_{4}$ lines that had been previous generated through crossing 7 parental lines, and then advanced in bulk from $\mathrm{F}_{1}$, was conducted in Namulonge-Wakiso, Olweny-Lira and Kibimba- Bugiri districts in Uganda. The study also included 7 parental lines and 6 popular varieties used in most farmers' fields. Variety IR 24 had been used as a universal check against BLB in Asian rice populations. Results revealed differential reactions on a set of near isogenic lines in the background of IR24, and some national and regional cultivars. IRBB1 (Xa1), IRBB2 (Xa2) and IRBB14 (Xa14) showed moderate susceptibility to susceptibility towards field pathogen populations in the three locations. Whereas genotype IRBB4 with gene Xa4 differentiated pathotypes of Kibimba and Lira from that of Namulonge, IRBB10 (Xa10) and IRBB11 (Xa11) differentiated pathotypes of Lira from the rest. Genotypes that had been pyramided with BLB genes of resistance, showed similar reactions to the three field populations. Generally, the near isogenic lines IRBB1, IRBB2, IRBB11 and IRBB14, had the highest leaf area damaged by disease attack. The highest was shown by IRBB11 with the Kibimba pathotypes for which disease attack was 43\%. Low attack was observed on pyramided genotypes in all locations and two with single gene, i.e. IRBB8 and IRBB21, respectively. Interestingly, IR24 was as resistant as any of the pyramided combinations. Results also revealed different reactions of the tested genotypes in the three locations. The analysis of variance by AMMI partitioned the main effects of treatments into genotype, environment, and genotype $\mathrm{x}$ environment $(\mathrm{G} \times \mathrm{E})$ interactions. Results also revealed that, the mean sum of squares due to treatments, genotypes, environments and genotype $\mathrm{x}$ environment interaction were significant, and contributed 48.2, 15.3, 19.3 and $13.3 \%$, respectively, PCA1 accounted for $73.02 \%$ of the total $\mathrm{G} \times \mathrm{E}$ sum of squares.
\end{abstract}

Key Words: Oryzae sativa, pyramid, Xanthomonas

\section{RÉSUMÉ}

La brûlure foliaire bactérienne (BLB) est causée chez le riz (Oryzae sativa L.) par Xanthomonas oryzae pv. oryzae qui est un problème majeur dans la plupart des basfonds ou on produit le riz en Ouganda. La maladie est largement répandue dans tous les écosystèmes ou le riz est produit, soit par irrigation ou par les pluies. L'agent pathogène (Xoo) présente une très grande diversification, et très difficile a Controller. Le développement et déploiement d'hôtes résistants est le seul moyen efficace pour le control du BLB. La présente étude visait à déterminer l'effet 
de l'interaction génotype-environnement $(\mathrm{GxE})$ sur la résistance à la bactérie de brulure foliaire chez le riz en Ouganda. Une expérimentation a été conduite sur 30 génotypes de riz, dont 13 lignées avec des niveaux de résistance variés à $\mathrm{BLB}$ et 17 lignées $\mathrm{F}_{4}$ générées en croissant 7 lignées parentales dont les $\mathrm{F}_{1}$ ont été avances a Namulonge-Wakiso, Olweny-Lira et Kibimba- Bugiri en Ouganda. L'étude a aussi pris en compte 7 lignées parentales et 6 variétés populaires utilisées dans la plupart des champs. La variété IR 24 a été utilisée comme référence universelle résistante au BLB dans les populations de riz asiatiques. Les résultats ont révélé des réactions diverses sur une série de lignées isogéniques par rapport à IR24, et quelques accessions nationales et régionales. IRBB1 (Xa1), IRBB2 (Xa2) et IRBB14 (Xa14) se sont montre peu ou très susceptibles au BLB dans les trois localités. Tandis que le génotype IRBB4 qui porte le gène Xa4 a réagi de façon différente vis à vis des pathotypes de Kibimba et de Lira compare à ceux de Namulonge, IRBB10 (Xa10) et IRBB11 (Xa11) ont différencié les pathotypes de Lira par rapport au reste. Les génotypes portant des cumuls de gènes de résistance ont exhibes des réactions identiques dans toutes les trois populations. Généralement, les lignées presque isogéniques IRBB1, IRBB2, IRBB11 et IRBB14, ont présenté les pourcentages les plus élevés de dommages foliaires. Les dommages les plus importants étaient observés chez IRBB11 en contact avec les pathotypes de Kibimba, pour lesquels on a noté $43 \%$ d'attaque foliaire. Dans toutes les localités, les dégâts étaient modérés sur les génotypes à plusieurs gènes de résistance et deux avec un seul gène. Par exemple, IRBB8 et IRBB21, respectivement. Fort heureusement, IR24 était autant résistant que tous les autres gènes cumulés. Il a été aussi observe que les réactions sur les génotypes testes varient d'une location a une autre. L'analyse de variance par AMMI a partitionne les effets des traitements en effet dus aux génotypes, a l'environnement et a leur interaction. Aussi, il a été observe que les sommes des carrés moyens due au traitements, génotypes, environnement et interaction génotypeenvironnement, étaient significatives et contribuent respectivement 48.2, 15.3, 19.3 et 13.3\% a la variation totale. L'axe PCA1 a expliqué $73.02 \%$ de la variation totale due à l'interaction $\mathrm{G}$ x E.

Mots Clés: Oryzae sativa, pyramide, Xanthomonas

\section{INTRODUCTION}

Bacterial leaf blight (BLB) of rice caused by Xanthomonas oryzae pv. oryzae (Swings et al. 1990), is widespread in several rice growing areas covering both tropical and temperate countries (Mew, 1987; Mew et al., 1993; Gnanamanickam et al., 1999; Séré et al., 2005). The disease occurs in fields in several West African countries with incidences as high as 70 to $80 \%$ (Séré et al., 2005). Yield losses due to BLB generally vary between 20 to $30 \%$, but a range from 50 to $90 \%$ has been reported in some areas (Ou, 1985; Séré et al.,2005).

The presence of X.oryzae pv. oryzae has now been confirmed in Uganda (Onasanya et al., 2010). However, little is known about the variability of local Xanthomonas oryzae pv.oryzae pathogen populations (Lamo, 2009). A recent survey reported the occurrence of bacterial leaf blight in some parts of rice growing areas of Eastern Uganda, with high incidence and severity (Lamo, 2009; Habarurema et al., 2012).

However, investigation of the resistance to bacterial leaf blight of rice varieties has not been evaluated. Chemical control of BLB is impractical, and no truly effective bactericide is commercilly available for its control (Ou, 1985). Some bacterial antagonists of Xoo tried as biological agents could not be used commercilly (Vasudevan et al., 2002). On the other hand, controlling the disease using cultural practices, by improving or changes in cultural practices, are only partially effective in restricting the pathogen from spread (NiñoLiu et al., 2006). Practicing field sanitation such as removing weed hosts, rice straws and debris, ratoons, and volunteer seedlings is important to avoid infection caused by this disease. Likewise, maintaining shallow water in nursery beds, providing good drainage during severe flooding, ploughing under rice stubble and straw following harvest, are also management practices that can be followed (Mizukami and Wakimoto, 1969). Proper seed dressing, application of judicious nitrogen fertiliser rates, proper plant spacing and crop rotation are also recommended for the management of BLB (IRRI, 2003). However, the usefulness of cultural practices for BLB control varies depending on the location and disease incidence (Niño-Liu et al., 2006).

The use of varietal resistance or breeding for BLB resistance is the main control measure presently available, since no other control 
method is economically effective (Niño-Liu et al., 2006). Several resistance genes are available for deployment against this disease. The utilisation of resistant varieties carrying $R$ genes, is one of the most effective, economical and environmentally friendly approach to control the bacterial blight (Keyu et al., 2008; Lore et al., 2011). Globally, BLB-resistant rice cultivars were developed and as many as $31 \mathrm{Xa}$ genes conferring resistance against Xoo have been identified so far (Nino Liu et al., 2006). However, the durability of resistance depends upon the prevalence of pathogen races in time and space (Jagjeet et al., 2010). This is due to the fact that the pathogen Xoo is highly variable and more than 30 races of the bacterium have been reported worldwide (Adhikari et al., 1999; Noda et al., 2001).

The objective of this study was to determine the nature of genetic variability for resistance to bacterial leaf blight (Xanthomonas oryzae pv oryzae) in selected Ugandan rice landraces and introduced varieties, derived from intraspecific and interspecific genotypes through determining the magnitude of $\mathrm{G} x$ E interaction of the selected genotypes.

\section{MATERIALS AND METHODS}

Experimental location. The study was conducted on three locations: Namulonge (Central-Uganda); Kibimba (Eastern-Uganda) and Olweny (Northern-Uganda). Namulonge, is located at $0^{\circ} 31^{\prime} 47^{\prime \prime} \mathrm{N}$ and $32^{\circ} 36^{\prime} 9^{\prime \prime} \mathrm{E}$, at an elevation of 1,133 meters above sea level (m.a.s.l). It has a bimodal type of rainfall, with an annual mean rainfall of $1,300 \mathrm{~mm}$, with the first rainy season from April to July and the second season in September to December. The site has a tropical wet and a mild dry climate, with slightly humid conditions averaging $65 \%$ humidity. Temperatures rarely rise beyond $28{ }^{\circ} \mathrm{C}$, with the minimum about $15^{\circ} \mathrm{C}$, and typically less than $70 \%$ relative humidity (Lugojja et al., 2001; NARO, 2005).

Kibimba Irrigation Scheme is located in eastern Uganda, at a latitude $0^{\circ} 32$ ' $14^{\prime \prime} \mathrm{N}$ and longitude 33051' 9"E, in Bugiri district. The irrigation scheme was started as a joint venture between Ugandan Government and the Peoples Republic of China. It has approximately 1,400 acres. This scheme was privatised in 1995 and it is currently under management of Tilda Ltd, a UK based-Indian company.

The Olweny Rice Scheme is located in Lira district in northern Uganda, at 2p 11' 49.3"N and 33p 1'33.3"E. The Olweny wetland system is about 10,000 hectares in size, including 600 hectares that have been developed into the Itek (350 ha) and Okile (250 ha) Rice Projects, located in Amach and Barr sub-counties. This region also has a bimodal type of rainfall.

Rice germplasm used. Two sets of germplasms were used in this study. The first set included a total of 30 rice genotypes, comprised of 13 lines, with varying levels of BLB resistance; and $17 \mathrm{~F}_{4}$ lines that had been previous generated through crossing 7 parental lines, and then advanced in bulk from $\mathrm{F}_{1}$. The 7 parents were included in the 13 lines used in the study (Table 1), while the remaining 6 were among the popular varieties used in most farmers' fields. These six varieties included K85 (local Ugandan landrace), NERICA1 (upland), IR54 (IRRI -Tanzania), IR 24, CT 12, WITA 9 (AfricaRice) and K5 (Ugandan landrace). Variety IR 24 had been used as a universal check against BLB in Asian rice populations. Meanwhile, K5 and K85 were the varieties most preferred in Uganda, though they were susceptible to BLB. CT12 is a newly released rice variety that had been successful in Uganda and was also resistant to BLB (Lamo, 2010).

The second set of germplasm consisted of differential lines comprising of 17 near-isogenic rice lines (NILs) based on IR24, with each NIL carrying one to four specific genes for resistance to BLB (Lore et al., 2011). The differentials were planted beside the genotypes tested at each trial site for the $\mathrm{G} \times \mathrm{E}$. These differential lines and their respective genes of resistance are listed in Table 2.

Experimental design. The 30 test genotypes were planted in three locations of Namulonge, Lira, and Kibimba. Seedlings were transplanted into a $10 \times 3$ alpha lattice design, with three replications and a plant spacing of $20 \mathrm{~cm} \times 20 \mathrm{~cm}$, with 2 seedlings per hill. In addition, the 17 NILs and IR24 were also planted alongside the experimental plots in 4 lines of $6.0 \mathrm{~m}$ long. 
TABLE 1. List of rice genotypes used in a study in Uganda

\begin{tabular}{|c|c|c|c|}
\hline No. & Genotype name & Pedigree & Source \\
\hline 1 & IR54 & Unknown & *IRRI-Tanzania \\
\hline 2 & NERICA4 & WAB450-I-B-P-91-HB & Africa Rice/WARDA \\
\hline 3 & CT145 & Unknown & ${ }^{* *} \mathrm{CIAT}$ \\
\hline 4 & CT12 & CT16344-CA-9-M & CIAT \\
\hline 5 & NERICA1 & WAB450-I-B-P-38-HB & Africa Rice/WARDA \\
\hline 6 & WITA9 & Unknown & Africa Rice/WARDA \\
\hline 7 & K5 & Cross & Uganda (Local) \\
\hline 8 & CT147 x WITA132 & Cross & ${ }^{* * *}$ NACRRI-Namulonge \\
\hline 9 & NERICA14 x WITA132 & Cross & NACRRI-Namulonge \\
\hline 10 & NERICA10 x NERICA14 & Cross & NACRRI-Namulonge \\
\hline 11 & NERICA4 x NERICA10 & Cross & NACRRI-Namulonge \\
\hline 12 & CT23 & CT16333(20)-CA-18-M & CIAT \\
\hline 13 & WITA132 x NERICA14 & Cross & NACRRI-Namulonge \\
\hline 14 & WITA132 & Unknown & Africa Rice/WARDA \\
\hline 15 & NERICA14 x CT145 & Cross & NACRRI-Namulonge \\
\hline 16 & NERICA14 & WAB880-1-32-1-2-P1-HB & Africa Rice/WARDA \\
\hline 17 & K85 & Unknown & Uganda (Local) \\
\hline 18 & NERICA10 & WAB450-11-1-1-P41-HB & Africa Rice/WARDA \\
\hline 19 & NERICA10 x WITA132 & Cross & NACRRI-Namulonge \\
\hline 20 & WITA132 x CT147 & Cross & NACRRI-Namulonge \\
\hline 21 & NERICA14 x CT23 & Cross & NACRRI-Namulonge \\
\hline 22 & CT147 & Unknown & CIAT \\
\hline 23 & WITA132 x CT145 & Cross & NACRRI-Namulonge \\
\hline 24 & NERICA4 $\times$ CT145 & Cross & NACRRI-Namulonge \\
\hline 25 & NERICA10 x CT147 & Cross & NACRRI-Namulonge \\
\hline 26 & WITA132 x CT147 & Cross & NACRRI-Namulonge \\
\hline 27 & CT145 x NERICA14 & Cross & NACRRI-Namulonge \\
\hline 28 & WITA132 x NERICA14 & Cross & NACRRI-Namulonge \\
\hline 29 & CT147 x NERICA4 & Cross & NACRRI-Namulonge \\
\hline 30 & NERICA14 x NERICA4 & Cross & NACRRI-Namulonge \\
\hline
\end{tabular}

${ }^{*}$ IRRI : International Rice Research Institute ${ }^{* *}$ CIAT: International Centre for Tropical Agriculture, ${ }^{* * *}$ NACRRI: National Crop Resource Research Institute

\section{Data collection and management}

BLB assessment on the NILs. Disease reaction on the NILs was recorded based on length of the leaf showing symptoms of BLB at crop maturity period. The length of the BLB lesion was then classified in accordance with Cottyn and Mew's system (2004).

BLB assessment on the 30 test genotypes. Data were collected on the 30 genotypes, by recording their disease score 42 days after transplanting, using the IRRI standard scoring scale (IRRI, 1996), (Table 3). This scale was used because estimated average percentages of disease attack on leaves for replicated plots were used during disease assessment in field

\section{Data analysis}

Pathotype diversity. The pathogenic variability of the Xoo was assessed on the basis of the extent of damage of Xoo on the differential lines, according to differences in their disease scores in the different locations. The mean disease scores for genotypes were then grouped according to Cottyn and Mew's (2004) classification. 
TABLE 2. Bacterial blight NILs and their genes of resistance to bacterial leaf blight (BLB)

\begin{tabular}{llllll}
\hline No & NIL & Xa-gene & NIL & Xa-gene & No. \\
\hline 1 & IRBB1 & Xa1 & IRBB50 & Xa4+xa5 & 10 \\
2 & IRBB2 & Xa2 & IRBB51 & Xa4+xa13 & 11 \\
3 & IRBB4 & Xa4 & IRBB52 & Xa4+Xa21 & 12 \\
4 & IRBB7 & Xa7 & IRBB54 & xa5+Xa21 & 13 \\
5 & IRBB8 & Xa8 & IRBB55 & xa13+Xa21 & 14 \\
6 & IRBB10 & Xa10 & IRBB56 & Xa4+xa5+xa13 & 15 \\
7 & IRBB11 & Xa11 & IRBB57 & Xa4+xa5+xa21 & 16 \\
8 & IRBB14 & Xa14 & IRBB60 & Xa4+xa5+xa13+xa21 & 17 \\
9 & IRBB21 & Xa21 & IR24 & - & 18
\end{tabular}

Source: Liu et al. (2007)

TABLE 3. Scale used for scoring bacterial leaf blight disease severity in rice in the field

\begin{tabular}{lcl}
\hline Scale & $\begin{array}{c}\text { Percentage of } \\
\text { Diseased } \\
\text { leaf area }\end{array}$ & Description \\
\hline 1 & $1-5$ & Resistant (R) \\
3 & $6-12$ & Medium resistant (MR) \\
5 & $13-25$ & Medium susceptible (MS) \\
7 & $26-50$ & Susceptible (S) \\
9 & $>50$ & Highly susceptible (HS) \\
\hline
\end{tabular}

Source: IRRI (1996)

Genotype by environment interaction analysis. Analysis of variance (ANOVA) for each location was done separately, followed by combined ANOVA across locations for the BLB resistance trait. Locations and replications were treated as random effects, while genotypes were treated as fixed effects. The ANOVA was performed using GenStat statistical package (Lawes Agricultural Trust, 2012). The linear model used for the single location ANOVA was:

$Y i j=\grave{i}+r i+g j+e i j$

Where:

Yij $=$ observed effect for ith replication and $\mathrm{jth}$ genotype;

ì = grand mean of the experiment;

ri $=$ effect of the ith replication; $\mathrm{gi}=$ effect of the $\mathrm{jth}$ genotype (f1 hybrid or inbred line); and

eij $=$ residual effect or random error of the experiment.

The linear model for the across-location ANOVA was (Habururema et al., 2012):

$Y i j k=\mu+l i+r(l) j(i)+g k+(g l) i k+e j k(i)$

Where:

Yijk $=$ observed effect for the $i$ th location, $j$ th replication within the $i$ th location, and $k$ th genotype;

$\mu=\quad$ grand mean of the experiment;

$\mathrm{li}=\quad$ effect of the $i$ th location;

$\mathrm{r}(\mathrm{l}) \mathrm{j}(\mathrm{i})=$ effect of the $j$ th replication within the $i$ th location;

$\mathrm{gk}=\quad$ effect of the $k$ th genotype (F1 hybrid);

$(\mathrm{gl}) \mathrm{ik}=$ interaction of the $k$ th genotype with the $i$ th location; and

ejk(i) $=$ residual effect or random error of the experiment.

Genotype stability for resistance to BLB disease. Genotype stability for resistance to BLB disease was determined using the additive main effects and multiplicative interaction (AMMI) analysis in GenStat $14^{\text {th }}$ edition statistical software (Lawes Agricultural Trust, 2012). The AMMI model used was:

$\mathrm{Y}_{\mathrm{ger}}=\mu+\mathrm{a}_{\mathrm{g}+} \hat{\mathrm{a}}_{\mathrm{e}+\mathrm{e} \mathrm{e}} \mathrm{y}_{\text {gnäen }}+{ }^{\tilde{\mathrm{n}}}{ }_{\mathrm{ge}}+\mathrm{E}_{\mathrm{ger}}$, 
Where:

$\mathrm{Y}=$ the BLB disease lesion of genotype $\mathrm{g}$ in environment e for replicate $\mathrm{r}$;

$\mu \quad=$ the grand mean;

$\mathrm{a}_{\mathrm{g}} \quad=$ the genotype $\mathrm{g}$ mean deviation;

$\hat{\mathrm{a}}_{\mathrm{e}}^{\mathrm{g}}=$ the environment $\mathrm{e}$ mean deviation;

ën $=$ the number of PCA axes retained in the model;

$\mathrm{n} \quad=$ the singular value for PCA axis $\mathrm{n}$;

$\mathrm{y}_{\mathrm{gn}}=$ the genotype eigenvector value for PCA axis n;

äen $=$ the environment eigenvector values for PCA axis n;

$\tilde{\mathrm{n}} \quad=$ the residual; and

$\mathrm{E}_{\text {ger }}^{\text {ge }}=$ the error (Ntawuruhunga et al., 2001).

An AMMI1 biplot was generated to provide visualisation of the main effects of the treatment and the environments, in addition to the most important treatment $x$ environment interactions. Another analysis was conducted using a biplot of genotype main effects plus genotype $\mathrm{x}$ environment interaction (GGE) to further visualise the genotype $\mathrm{x}$ environment two-way interaction.
The GGE biplot allows visualisation of the crossover treatment $\mathrm{x}$ environment interactions, relationships among treatments, and relationships among environments.

\section{RESULTS}

Pathotype diversity of Xanthomonas oryzae pv oryzae (Xoo). Results of the near isogenic lines (NILs) evaluated in three locations, revealed differences in their reaction patterns to BLB isolates on the NILs (Table 4).

Genotype RBB1 (Xal), IRBB2 (Xa2) and IRBB14 (Xa14) showed moderately susceptible to susceptible toward the field pathogen populations in all three locations. These three genotypes, each contain a single gene of resistance to BLB. Whereas genotype IRBB4 (Xa4) differentiated pathotypes of Kibimba and Lira from of Namulonge, IRBB10 (Xa10) and IRBB11 (Xa11) differentiated pathotypes of Lira from the rest. IRBB1 (Xa1), IRBB2 (Xa2) and IRBB14 (Xa14) showed moderately susceptible to susceptible toward the field pathogen populations in all three locations. Each genotype

TABLE 4. Reaction of NILs against the natural pathogen populations in the different locations

\begin{tabular}{|c|c|c|c|c|}
\hline \multirow[t]{2}{*}{ Genotype/NIL } & \multirow[t]{2}{*}{ Xa gene } & \multicolumn{3}{|c|}{ Reaction against pathotypes } \\
\hline & & NamXoo (Namulonge) & KbXoo (Kibimba) & LiXoo (Lira) \\
\hline IRBB 1 & Xa1 & $S$ & $S$ & MS \\
\hline IRBB 2 & Xa 2 & MS & $S$ & MS \\
\hline IRBB 4 & Xa4 & MS & MR & MR \\
\hline IRBB 7 & Xa 7 & MR & MS & MR \\
\hline IRBB 8 & Xa 8 & MR & MR & $\mathrm{R}$ \\
\hline IRBB10 & Xa 10 & MS & MS & MR \\
\hline IRBB11 & $X a 11$ & $S$ & $S$ & MR \\
\hline IRBB14 & Xa 14 & $S$ & MS & MS \\
\hline IRBB21 & Xa 21 & $\mathrm{R}$ & $\mathrm{R}$ & $\mathrm{R}$ \\
\hline IRBB50 & $X a 4+X a 5$ & MR & MR & $\mathrm{R}$ \\
\hline IRBB51 & $X_{a} 4+X a 13$ & MR & MS & MR \\
\hline IRBB52 & $X a 4+X a 21$ & MR & $\mathrm{R}$ & $\mathrm{R}$ \\
\hline IRBB54 & $X a 5+X a 21$ & $\mathrm{R}$ & $\mathrm{R}$ & $\mathrm{R}$ \\
\hline IRBB55 & $X a 13+X a 21$ & $\mathrm{R}$ & $\mathrm{R}$ & $\mathrm{R}$ \\
\hline IRBB56 & $X a 4+X a 5+X a 13$ & $\mathrm{R}$ & $\mathrm{R}$ & $\mathrm{R}$ \\
\hline IRBB57 & $X a 4+X a 5+X a 21$ & $\mathrm{R}$ & $\mathrm{R}$ & $\mathrm{R}$ \\
\hline IRBB60 & $X a 4+X a 5+X a 13+X a 21$ & $\mathrm{R}$ & $\mathrm{R}$ & $\mathrm{R}$ \\
\hline IR24 & - & $\mathrm{R}$ & MR & $\mathrm{R}$ \\
\hline
\end{tabular}

$\mathrm{R},=$ resistant., MR, = moderately resistant., MS, = moderately susceptible., $\mathrm{S}$, = susceptible 
contained a single gene of resistance to BLB. Whereas genotype IRBB4 with gene $\mathrm{Xa} 4$ differentiated pathotypes of Kibimba and Lira from that of Namulonge, IRBB10 (Xa10) and IRBB11 (Xa11) differentiated pathotypes of Lira from the rest. Genotypes that had been pyramided with BLB genes of resistance, showed similar reaction to all three field populations.

Generally, the near isogenic lines IRBB1, IRBB2, IRBB11 and IRBB14 had the highest percentages of leaf area damaged by disease attack. The highest was shown by IRBB11 with the Kibimba pathotype (KibXoo) for which disease attack was $43 \%$ (Fig. 1). Low attack was observed on pyramided genotypes in all locations and two with single gene, i.e., IRBB8 and IRBB21, respectively. Interestingly, IR24 was as resistant as any of the pyramided combinations.

Genotype by environment interaction. Analysis of variance (ANOVA) across environments, detected significant variation among genotypes and for the $\mathrm{G} \times$ E interaction on the BLB resistance trait. This phenomenon indicated differences in response to the environments of the genotypes used in the study as shown by in Figure 1.

Stability of BLB-resistant rice genotypes. The analysis of variance by AMMI partitioned the main effects of treatments into genotype, environment, and genotype $\mathrm{x}$ environment $(\mathrm{G} x$ E) interactions. Results revealed that, the mean

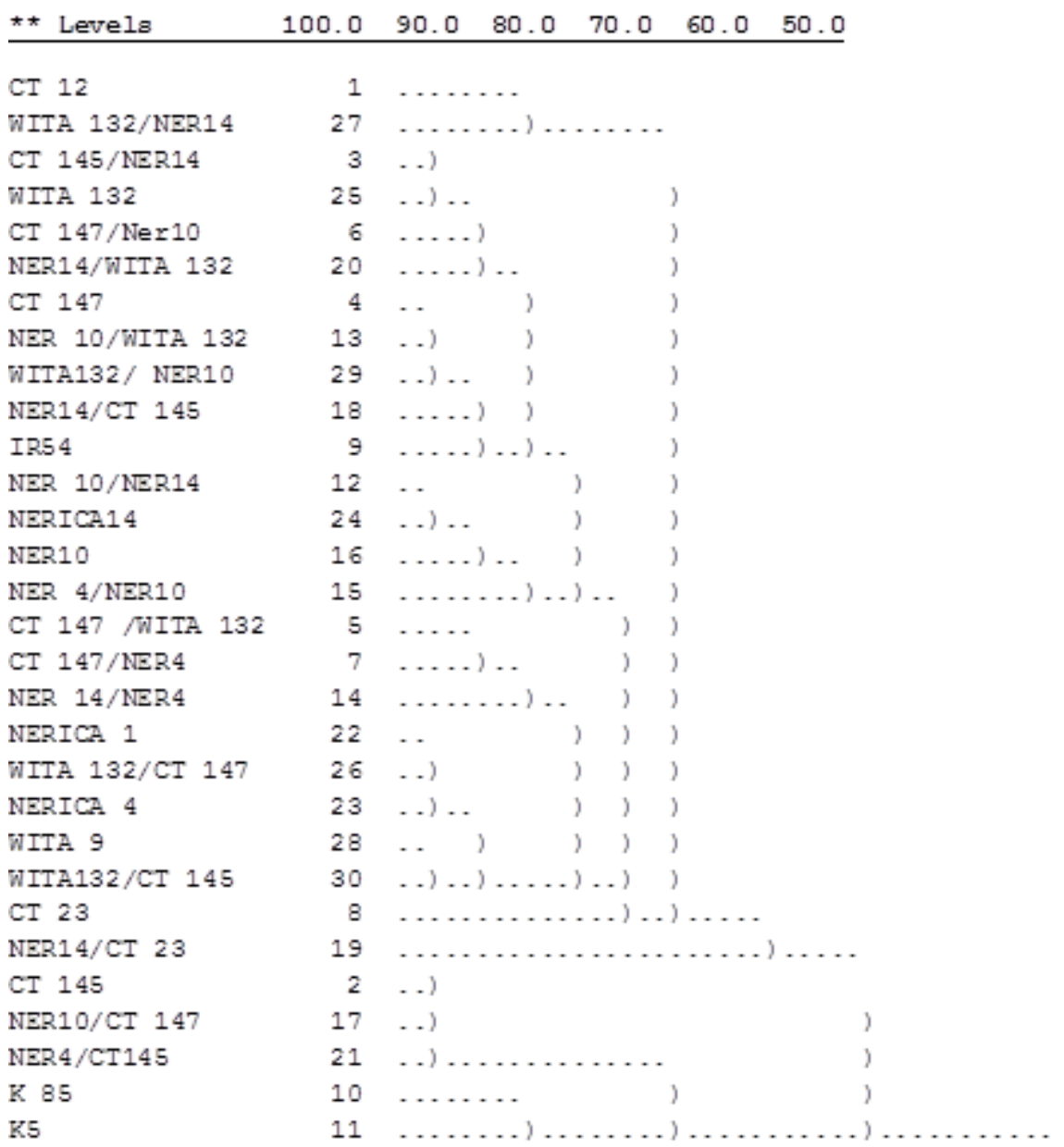

Figure 1. Dendrogram of the genotypes tested for BLB in three locations in Uganda 2011. 
sum of squares due to treatments, genotypes, environments and genotype $\mathrm{x}$ environment interaction were significant, and contributed 48.2, 15.3, 19.3 and $13.3 \%$, respectively. PCA1 accounted for $73.02 \%$ of the total G x E sum of squares.

In order to determine whether bi-plot analysis was suitable, a mean value of BLB score against PCA 1 scores were conducted (Fig. 2).

Since a high number of genotypes with PCA scores close to zero were realised, bi-plot analysis was employed. For the 30 genotypes tested, 11 genotypes about $37 \%$ had a mean score outside of the range of \pm 0.5 . These were NERICA4, K5, CT147 x WITA132, NERICA14 x WITA132, NERICA4 x NERICA10, NERICA14 x CT145, NERICA14, NERICA10, CT147, WITA132 x CT147 and CT145 x NERICA14 (Fig. 3).

The variation of genotypes in two clear environmental clusters with environment 1 and 3 , together and environment 2 separate was depicted in Figure 3. Similarly, the AMMI 2 revealed four apparent groups of the genotype in terms of response to the environment. Each group was on both sides of the quadrants of the biplot. Several lines showed low score for BLB in each of the quadrants.

The results for IPCA scores and means of 30 genotypes in 3 environments showed that many genotypes were highly interactive (Table 5). The most resistant genotypes across the different locations were CT12 (10.64\%), WITA 132
xNERICA14 (13.66\%), NERICA10(18.3\%), NERICA4 (18.31\%) and NERICA1 (18.54\%). The least resistant genotypes included two local checks (K5 (34.46\%) and K85 (34.07\%), as well as CT145 (28.91\%) and NERICA14 x CT23 (30.01\%). Results also indicated that most of the genotypes were affected by the disease at Kibimba, with a mean of $30.99 \%$; and less so at Lira site (17.39\%). It was also shown that, the most interactive genotypes included NERICA14 x CT23 and K5 (2.0) interpreted from their IPCA1 values; while the least interactive genotype was NERICA10 which recorded an IPCA1 value of -0.05 (Table $6)$.

The GGE biplot based on the 30 genotypes at 3 environments (Namulonge, Kibimba and Lira) in a two-way table of the BLB score is illustrated in Figure 4. The environment-standardised data are used, with the assumption that all environments were equally important in genotypic evaluation. The GGE biplot explained $91.28 \%$ of the BLB score for resistance, when the analysis was environment-centred. NERICA14 $\mathrm{x}$ CT23 had the least resistance to BLB in Kibimba; while K5 and K85 scored least resistance to BLB in both Lira and Namulonge. This environmentfocused singular-value partitioning, allows appropriate visualisation of the relationships among environments and similar overlapping clusters of environments, as shown in the AMMI analysis. The biplot Figure 4 also, revealed four apparent groups of the genotype in terms of their

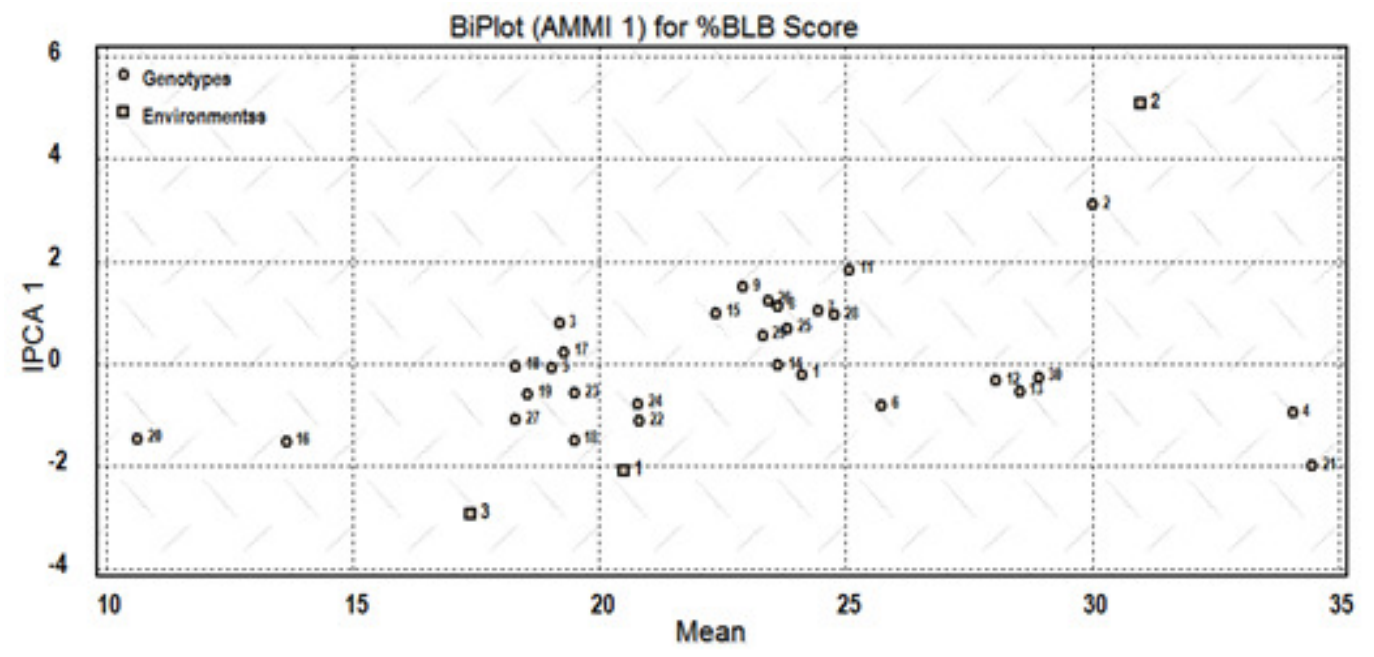

Figure 2. Graph for percentage mean BLB score against IPCA 1 score for a study in Uganda. 


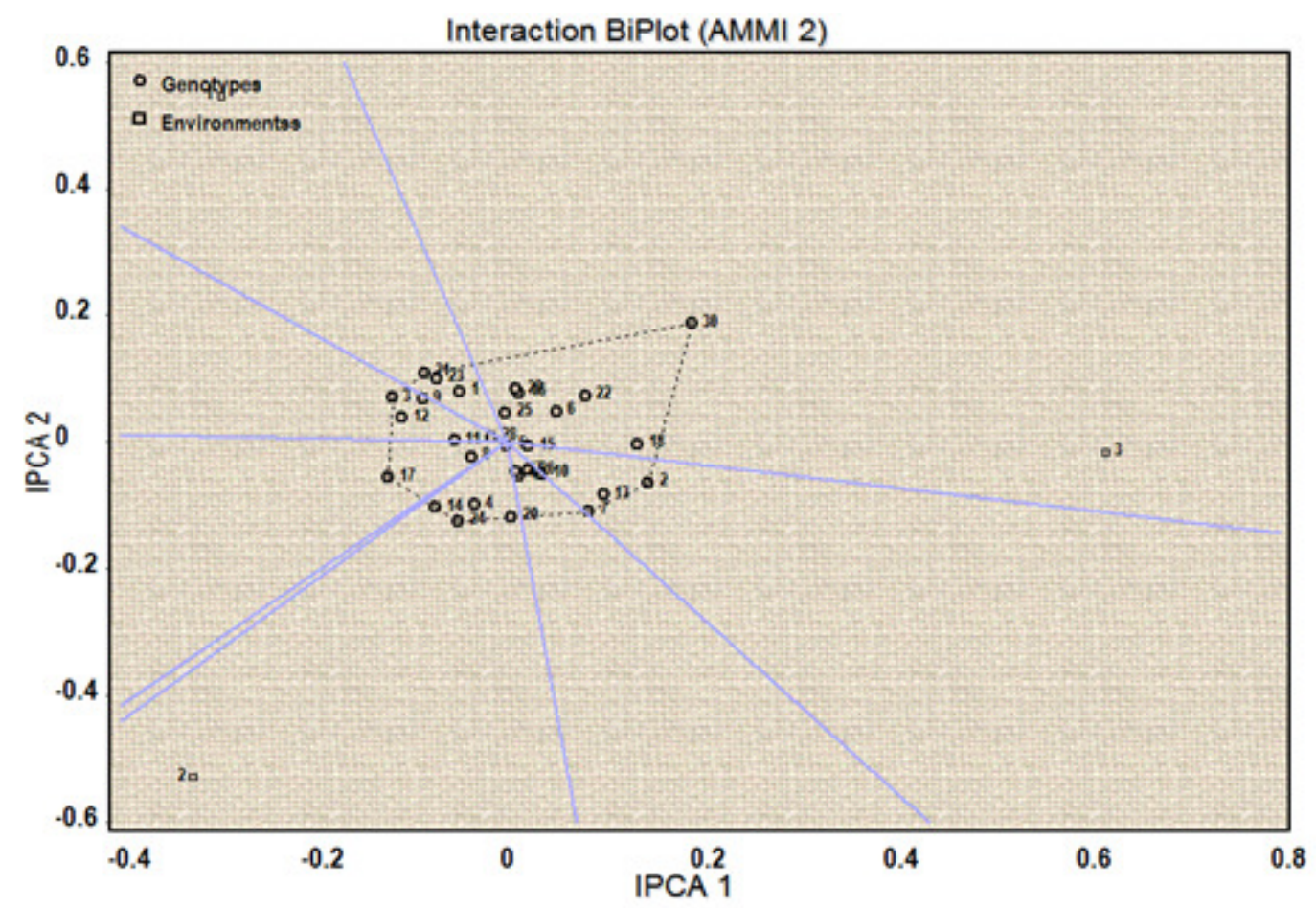

Figure 3. Biplot of IPCA 2 against IPCA 1 for \% BLB score of 30 genotypes at locations of Uganda.

response to the environment. Each group was on both sides of the quadrants of the biplot. Several lines showed low scores for BLB in each of the quadrants. The analysis further revealed that there was moderate genotype $\mathrm{x}$ environment interaction $(13.3 \%)$ relative to the main effect (15.3\%), which led to moderate crossover genotype $\mathrm{x}$ environment interactions, as evidenced by the fact that PC1 scores took different signs and the 3 environments fell in only two quadrants in terms of their discrimination of genotypes for BLB score.

\section{DISCUSSION}

BLB pathotype reaction patterns. The reaction pattern of the 18 near isogenic lines (NILs) in the three locations, ranged from moderately susceptible to susceptible for IRBB1 (Xal), IRBB2 $(\mathrm{Xa2})$ and IRBB14 (Xa14). These three genotypes have single genes for resistance. In addition, genotype IRBB4 (Xa4) differentiated pathogen populations of Kibimba and Lira from that of Namulonge; while IRBB10 (Xa10) and IRBB11
(Xa11), being moderately resistant, differentiated pathogen populations of Lira from the rest, IRBB21 ( $X a$ 21) showed resistance in all three locations. The study findings contradict those of Goel et al. (1998) and Swamy et al. (2006), who reported that IRBB21 ( $\mathrm{Xa}$ 21) was non-responsive to all pathotypes found in India. However, another study conducted in Punjab, revealed that IRBB21 was the most resistant against 17 BLB isolates (Singh et al., 2003).Similar results were reported by Mazzola et al. (1994), who noted that IRBB21 was resistant to all pathotypes of Xoo prevalent in India and the Philippines.

This finding suggests that single genes could be used to develop BLB resistant lines through pyramiding. Lines with pyramided genes, including IRBB50, IRBB52, IRBB54, IRBB55, IRBB56, IRBB57 and IRBB60, were at least moderately resistant in all three locations, in contrast with single-gene isolines, which had varying and often susceptible reactions. This further supports the view that pyramiding is an appropriate breeding approach for developing resistance to BLB. Singh et al. (2001) indicated 
TABLE 5. Mean percentage of BLB lesions on the tested genotypes from the three locations in Uganda

\begin{tabular}{|c|c|c|c|c|}
\hline \multirow[t]{2}{*}{ Genotype } & \multicolumn{3}{|c|}{ Mean \% bacterial leaf blight lesion } & \multirow{2}{*}{$\begin{array}{c}\text { Genotype } \\
\text { mean }\end{array}$} \\
\hline & Namulonge & Kibimba & Olweny & \\
\hline CT $147 \times$ x NERICA 4 & 22.09 & 31.08 & 19.16 & 24.11 \\
\hline NERICA14 x CT 23 & 21.00 & 53.75 & 15.28 & 30,01 \\
\hline NERICA 4 x NERICA10 & 15.07 & 31.19 & 11.30 & 19.19 \\
\hline K85 & 33.64 & 37.21 & 31.35 & 34.07 \\
\hline NERICA10 x NERICA14 & 16.77 & 26.58 & 13.75 & 19.03 \\
\hline NERICA14 x NERICA 4 & 24.99 & 29.64 & 22.57 & 25.73 \\
\hline NERICA14 x WITA 132 & 19.79 & 37.69 & 15.81 & 24.43 \\
\hline NERICA10 $\times$ WITA 132 & 18.79 & 37.38 & 14.73 & 23.63 \\
\hline NERICA14 x CT 145 & 17.29 & 38.52 & 12.92 & 22.91 \\
\hline NERICA10 & 15.94 & 26.08 & 12.88 & 18.30 \\
\hline IR 54 & 18.77 & 42.35 & 14.12 & 25.08 \\
\hline NERICA $4 \times$ CT 145 & 26.30 & 34.35 & 23.48 & 28.04 \\
\hline NERICA10 x CT 147 & 27.21 & 33.80 & 24.56 & 28.52 \\
\hline CT 147 x WITA 132 & 21.24 & 31.46 & 18.17 & 23.62 \\
\hline CT 147 & 17.82 & 35.39 & 13.88 & 22.37 \\
\hline WITA 132 x NERICA14 & 14.40 & 14.01 & 12.57 & 13.66 \\
\hline NERICA14 & 16.35 & 28.47 & 13.05 & 19.29 \\
\hline СТ 23 & 20.20 & 19.90 & 18.36 & 19.49 \\
\hline NERICA1 & 17.34 & 23.56 & 14.74 & 18.54 \\
\hline CT 12 & 11.29 & 11.22 & 9.42 & 10.64 \\
\hline K5 & 36.21 & 32.36 & 34.79 & 34.46 \\
\hline WITA 132 x CT 145 & 20.74 & 23.15 & 18.58 & 20.82 \\
\hline WITA 132 x CT 147 & 18.29 & 24.57 & 15.67 & 19.51 \\
\hline WITA9 & 19.98 & 24.86 & 17.53 & 20.79 \\
\hline CT $145 \times$ NERICA14 & 19.90 & 35.35 & 16.22 & 23.82 \\
\hline WITA 132 x NERICA10 & 18.38 & 37.65 & 14.24 & 23.42 \\
\hline NERICA4 & 18.18 & 20.75 & 16.01 & 18.31 \\
\hline CT $147 \times$ NERICA 10 & 20.31 & 37.57 & 16.41 & 24.77 \\
\hline WITA132 & 19.70 & 34.10 & 16.13 & 23.31 \\
\hline CT 145 & 27.01 & 35.60 & 24.13 & 28.91 \\
\hline Location mean & 20.50 & 30.99 & 17.39 & 22.96 \\
\hline F-test & * & $* * *$ & $* * *$ & \\
\hline
\end{tabular}

that pyramided lines with more than one $X a$ gene among $X a 4, X a 5, X a 13$ and $X a 21$ had increased effectiveness against all isolates from Punjab.

The significance of $\mathbf{G} \mathbf{X} \mathbf{E}$. Genotypes, environments and their interactions were significant, contributing $15.3,19.3$ and $13.3 \%$ of the genetic variation, respectively. This indicates adequate variability worth using AMMI and GGE to detect and describe the performance of the genotypes response to BLB. The significance of the differences among environments indicated distinctness of intrinsic factors in the different environments. The AMMI 1 biplot explained $99.9 \%$ of the total variation, partitioned into PCA1 $=73.02 \%$ and PCA $2=26.97 \%$.

AMMI 1 plot showed that out of 30 genotypes, $11(37 \%)$ had a mean IPCA1 score outside the range of \pm 0.5 . The PC1 vs PC2 plot showed that 18 of the 30 genotypes had low interactions with environments for BLB scores. The overall result indicates adequate variability in the NILs to warrant the development of resistant lines. Furthermore, two clear clusters of 
TABLE 6. Mean percentage BLB score and interaction scores of the genotypes across locations in Uganda

\begin{tabular}{|c|c|c|}
\hline Genotype & BLB score $(\%)$ & IPCA 1 \\
\hline CT147 x NERICA4 & 24.11 & -0.21 \\
\hline NERICA14 x CT23 & 30.01 & 3.1 \\
\hline NERICA4 x NERICA10 & 19.19 & 0.78 \\
\hline K85 & 34.07 & -0.96 \\
\hline NERICA10 x NERICA14 & 19.03 & -0.1 \\
\hline NERICA14 x NERICA4 & 25.73 & -0.81 \\
\hline NERICA14 x WITA132 & 24.43 & 1.03 \\
\hline NERICA10 x WITA132 & 23.63 & 1.13 \\
\hline NERICA14 x CT145 & 22.91 & 1.5 \\
\hline NERICA10 & 18.3 & -0.05 \\
\hline IR 54 & 25.08 & 1.82 \\
\hline NERICA4 x CT145 & 28.04 & -0.34 \\
\hline NERICA10 x CT147 & 28.52 & -0.54 \\
\hline CT147 x WITA132 & 23.62 & -0.04 \\
\hline CT147 & 22.37 & 0.99 \\
\hline WITA132 x NERICA14 & 13.66 & -1.51 \\
\hline NERICA14 & 19.29 & 0.23 \\
\hline СТ 23 & 19.49 & -1.5 \\
\hline NERICA1 & 18.54 & -0.59 \\
\hline CT 12 & 10.64 & -1.47 \\
\hline K 5 & 34.46 & -2 \\
\hline WITA 132 x CT 145 & 20.82 & -1.12 \\
\hline WITA132 x CT147 & 19.51 & -0.58 \\
\hline WITA9 & 20.79 & -0.78 \\
\hline CT $145 \times$ NERICA 14 & 23.82 & 0.69 \\
\hline WITA132 x NERICA10 & 23.42 & 1.22 \\
\hline NERICA4 & 18.31 & -1.1 \\
\hline CT147 x NERICA10 & 24.77 & 0.94 \\
\hline WITA132 & 23.31 & 0.54 \\
\hline CT145 & 28.91 & -0.26 \\
\hline
\end{tabular}

environments suggest that breeding for multiple target environments could be necessary.

Several genotypes were highly interactive, implying that selection for stability across locations is useful. In this study, the identified lines with stable resistance for BLB were: CT12, WITA132 xNERICA14, NERICA10, NERICA4 and NERICA1. The resistance for BLB in these lines should be explored other enshrinements.

AMMI analysis revealed that many genotypes had significant $\mathrm{G} \times$ E interactions $(\mathrm{P}<$ 0.01). Olweny (Lira), located in eastern Uganda, showed the lowest overall BLB score for the tested genotypes, with an average mean disease percentage of $17.4 \%$; followed by Namulonge with $20.5 \%$. The variation in the AMMI analysis could be due to a number of factors, such as amount of rainfall, temperature, relative humidity, pests or BLB pathotypes. Although AMMI allows visualization of the main effects of the BLB score for the different genotypes and the environments, it does not show which genotype was consistently the most resistant in all locations. The which-won-where pattern can be visualised only by the polygon view of the GGE biplot. The consistently high BLB score for K5 and K85 in both Lira and Namulonge, confirms that these new lines are indeed susceptible to BLB. These are the two improved varieties along with landraces that farmers had started abandoning them due to their susceptibility to bacterial leaf blight and other diseases.

\section{CONCLUSION}

AMMI has indicated significant interactions reflecting differences in the genotypes, depending on the environment in which they are tested. These results emphasize that the environment contributes to differential genotype reactions to $\mathrm{BLB}$, and hence, to obtain true resistant genotypes there is a need for using multi-locations with several seasons of testing. There is a need to evaluate different isolates from each test environment to separate the effects of the physical environment from differences caused by differing pathotypes.

This information could be applied in breeding programmes to develop rice cultivars with durable resistance to the BLB pathogen. Furthermore, as Xoo is a seedborne, regional or international monitoring of the pathogen can be utilised in the quarantine programmes.

Due to diverse agro-climatic rice growing zones as the case shown by the three sites, and the presence of a number of genetically distinct virulent Xoo strains in Uganda, pyramiding of two or more effective $x a$ genes in agronomically superior genotypes and search for new disease resistance in context of African origin from wild oryza spp seems to be the most effective disease management strategy in our region. 


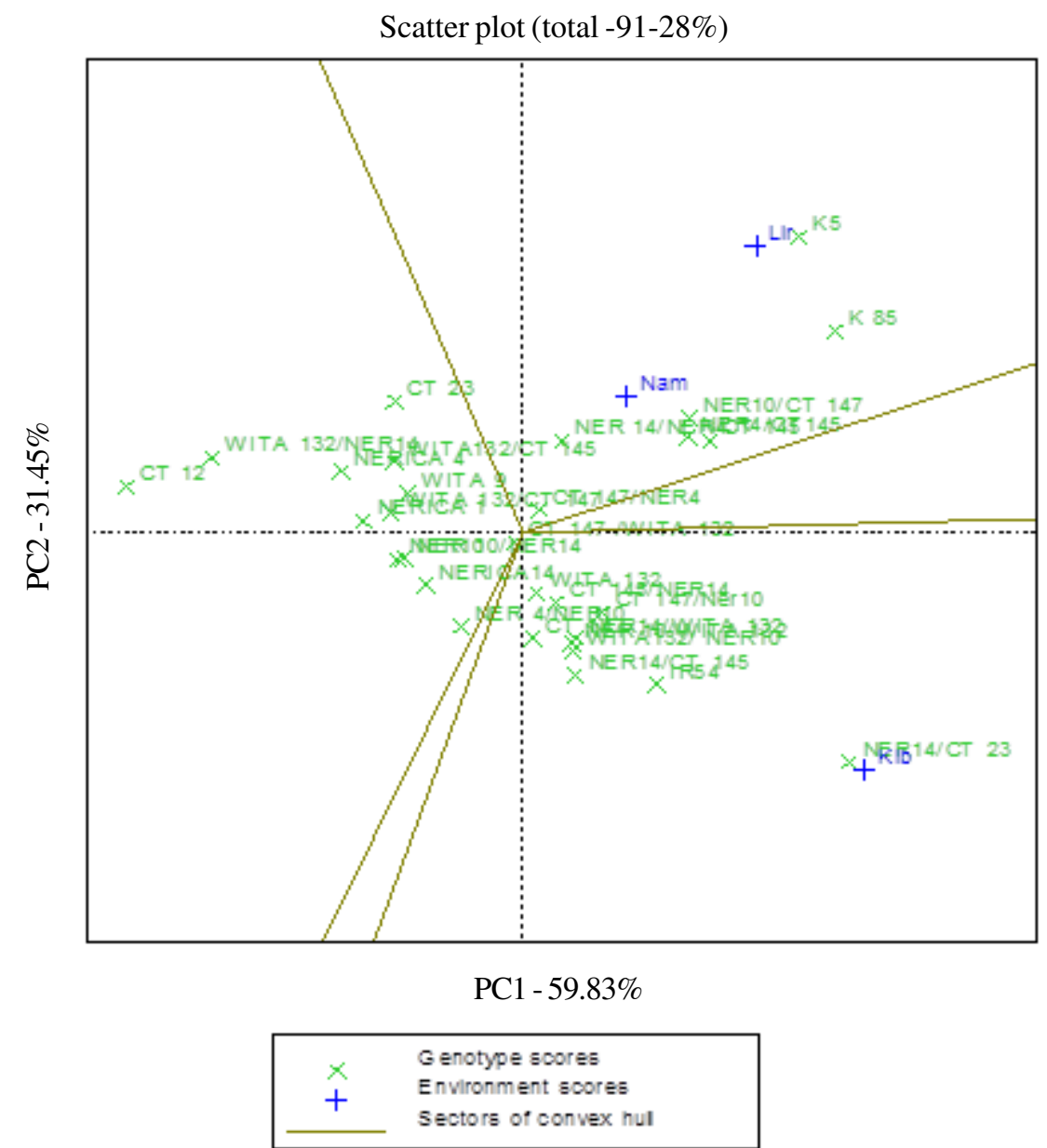

Figure 4. Distribution and performance of the genotypes against $X$. oryzae pv oryzae in the locations in Uganda.

\section{ACKNOWLEDGEMENT}

We thank the Regional Rice Centre of Excellence under the Eastern Africa Agricultural Productivity Project (EAAPP) for funding this work. Association for Strengthening Agricultural Research in Eastern and Central Africa (ASARECA) for facilitated the publication of this paper.

\section{REFERENCES}

Adhikari, T.B., Mew, T.W. and Leach, J.E. 1999.

Genotypic and pathotypic diversity in Xanthomonasoryzaepv.oryzae in Nepal. Phytopathology 89:687-694
Clewer, A.G. and Scarisbrick, D. H. 2001. Practical: Statistics and experimental design for plant and crop science. John Wiley and sons, Chichester.

Cottyn, B. and Mew, T.W. 2004. Bacterial blight in rice. In: Goodman, R.M. (Ed.). Encyclopedia of Plant and Crop Science. New York, Marcel Dekker. pp. 79-83.

Gnanamanickam, S.S., Pryiyadarasani, V., Narayanan, N., Vasudevan, N. and Kavitha, P. 1999. An overview of bacterial blight disease of rice and strategies for management. Curr. Sci. 77: 1435-1444.

Goel, R.K., Kaur, L. and Saini, R.G. 1998. Effectiveness of different $x a$ genes against Xanthomonas oryzae pv oryzae population 
causing bacterial blight of rice in Punjab (India). Rice Gen Newsl 15: 131-133

Habarurema, I., Asea, G., Lamo, J., Gibson, P., Edema, R., Se're,'Y. and Onasanya, R.O. 2012. Genetic analysis of resistance to rice bacterial blight in Uganda. Africa Crop Science Journal 20 Issue Supplement sl :105-112.

IRRI. 1996. Standard Evaluation System for Rice (SES). International Rice Research Institute (IRRI). The International Network for Genetic Evaluation of Rice-INGER, Genetic Resources Center, $4^{\text {th }}$ Edition, IRRI, Manila, Philippines.

IRRI. 2003. Rice Doctor. International Rice Research Institute. Manila, Philippines.

Jagjeet, S.L., Vikal, Y., Hunjan, M.S., Goel, R.K., Bharaj, T.S. and Raina, G.L. 2010. Jagjeet S.L., Vikal Y., Hunjan, M.S., Goel, R.K., Bharaj, T.S. and Raina, G.L. 2010. Genotypic and pathotypic diversity of Xanthomonas oryzae pv.oryzae, the cause of bacterial blight of rice in Punjab State of India. Journal of Phytopathology 159:479-487.

Keyu, G.U., Jatinder, S. S., Yin,Li and Zhongchao, Y. 2008. High-resolution genetic mapping of bacterial blight resistance gene $\mathrm{Xa} 10$. TheorAppl Genet 116:155-163.

Lamo, J. 2009. Genetic studies on drought tolerance and grain shattering in rice. A Thesis submitted in partial fulfillment of the requirements for the degree of Doctor of Philosophy (PhD) in Plant Breeding.

Lamo, J., Imanywoha, J., Bigirwa, G., Walusimbi, M., Kyetere, D., Kikafunda, J. and Kalule, T. 2010. First NERICA rice released in Uganda tops farmers' rankings. Genetic resources. International Rice Research Notes (IRRN) 0117-4185.

Lawes Agricultural Trust, 2012. GenStatstatistical software: Genstat for window discovery. $14^{\text {th }}$ edition International Ltd.Rothamsted, UK

Lore, J.S., Vikal, Y., Hunjan, M.S., Goel, R.K., Bharaj, T.S. and Raina, G.L. 2011. Genotypic and pathotypic diversity of Xanthomonas oryzae pv. oryzae, the cause of bacterial blight of rice in Punjab State of India. Journal of Phytopathology. pp. 1-9.

Lugojja, F., Ogenga-Latigo, M.W. and Smit, N.E.J.M. 2001. Impact of defoliation on the agronomic performance of sweetpotato in
Uganda. African Crop Science Journal 9:103-108

Mazzola, M., Leach, J. E., Nelson, R and White, F.F. 1994. Analysis of interaction between Xanthomonas oryzae pv. oryzae and the rice cultivar IR24 and IRBB21. Phytopathology 84: 392-397

Mew T.W. 1987. Current status and future prospects of research on bacterial blight of rice. Annual Reviews of Phytopathology 25:359-382.

Mew, T.W., Alvarez, A.M., Leach, J.E and Swings, J. 1993. Focus on bacterial blight of rice. Plant Disease 77 (1):5-12.

Mizukami, T. and Wakimoto, S. 1969. Epidemiology and control of bacterial leaf blight of rice. Annual Reviews of Phytopathology 7:51-72.

NARO. 2005. National Agricultural Research Organization (NARO): Final report for Rockefeller Food Security Project: Participatory multiplication and testing of improved upland rice varieties in Uganda, Namulonge Agricultural and Animal Production Research Institute, Kampala, Uganda

Nino-Liu, D.O., Ronald, P.C.and Bogdanove, A. J.2006. Xanthomonasoryzaepathovars: Model pathogens of a model crop. Mol. Plant Pathol. 7:303-324.

Noda, T., Li, C., Li, J., Ochiai, H., Ise, K. and Kaku, H. 2001. Pathogenic diversity of Xanthomonas oryzae pv. oryzae strains from Yunnan province, China. Japanese Agric Res Q35:97-103.

Ntawuruhunga, P.H., Rubaihayo, P., Whyte, J.B.A., Dixon, A.G.O. and Osiru, D.S.O. 2001. Additive main effects and multiplicative interaction analysis for storage root yield of cassava genotypes evaluated in Uganda. African Crop Science Journal 9:591-598.

Onasanya, A., Basso, A., Somado, E., Gasore, E.R., Nwilene, F.E., Ingelbrecht, I., Lamo, J., Wydra K., Ekperigin, M.M., Langa, M., Oyelakin, O., Séré, Y., Winter, S. and Onasanya, R.O. 2010. Development of a combined molecular diagnostic and DNA fingerprinting technique for rice bacteria pathogens in Africa. Asian network for scientific information. Biotechnology 9(2):89-105. 
Singh, S., Sidhu, J.S., Huang, N., Vikal, Y., Li Z., Brar, D.S., Dhaliwal, H.S and Khush, G.S. 2001. Pyramiding three bacterial blight resistance genes ( $x a 5, x a 13$ and $x a 2$ ), using markerassisted selection into indica rice cultivar PR106. Theor Appl Genet 102: 1011-1015.

Singh, S., SodhiM., Vikal, Y., George, M.L.C., Bala, G.S., Mangat, G.S., Garg, M., Sidhu, J.S. and Dhaliwal, H.S. 2003. DNA fingerpriting and virulence analysis of Xanthomonas oryzae pv. oryzae isolated from Punjab, northern India. Euphytica 130: 107-115

Swamy, P., Panchbhai, A.N., Dodiya, P., Naik V., Panchbhai, S.D., Zehr, U.B., Azhakanandam,
K. and Char, B.R. 2006. Evaluation of bacterial blight resistance in rice lines carrying multiple resistance genes and $x a 21$ transgenic lines. Curr sci90: 818-824

Swings, J., Van der Mooter, M., Vauterin, L., Hoste, B., Gillis, M., Mew, T.W. and Kersters, K. 1990. Reclassification of the causal agents of bacterial leaf blight (Xanthomonas campestris pv.oryzae) and bacterial leaf streak (Xanthomonas campestris pv.oryzicola) of rice as pathovars of Xa nthomonas oryzae (ex Ishiyama, 1922). Inter. J. of Systematic Bacteriology 40:309-311. 